British Museum (Natural History) : Acquisitions

The Trustees of the/British Museum (Natural History) have acquired, partly by purchase and partly by presentation, from Mrs. Lorna Tillotson, one half of a new neteorite which fell at Beddgelert, Caernarvonshire on September 21. The other half is to go to the U/fiversity of Durham, where Prof. F. A. Paneth plans to make measurements of the helium, uranium gnd thorium content to add to the present meagre data available for calculating the age of metedritic stones. Plaster casts of the stone will be made before it is divided. The meteorite is a black chondrite, a rather uncommon type of stony meteorite. The mineral composition has not been studied at present. Its arrival was accompanied by several loud explosions likened by Mr. Tillotson to heavy gunfire. Mr. Tillotson, by noting the positions of the holes in the roof and in the ceiling of the room into which the meteorite fell, determined that the angle of its fall on to the roof was nearly vertical. Very few reports have been received about the light or sound phenomena accompanying the fall. Those so far received are from three localities in Caernarvonshire, Lancashire and Cheshire. Any records of the passage of a meteor over Great Britain or Ireland would, therefore, be of interest, and should be sent either to Prof. Paneth or to Dr. W. Campbell Smith, Keeper of Minerals, British Museum (Natural History), London, S.W.7.

The Museum has also received a collection of birds, including kingfishers, owls, pigeons and birds of paradise, and mammals, all of which were collected in New Guinea by Mr. F. Shaw-Mayer. Mr. Michael Cox has presented a collection of 114 beautifully preserved plants, which he made in a largely unexplored area of north-west British Columbia, and which includes flowering plants, mosses, liver. worts, lichens and fungi. $\mathbf{8 , 3 0 0}$ microscope slides illustrating the anatomy of the genus Equisetum, and forming the collection made by the late Lady Isabel M. P. Browne, the leading authority on the anatomy of this genus for many years, has been received through Prof. F. W. Jane, Royal Holloway College, University of London. Prof. W. T. Gordon, recently professor of geology, King's College, London, has presented minerals and rocks from various localities in South Africa, Novaya Zemlya and Russia. Three pieces of the meteoric iron from Canon Diablo, the famous meteorite crater in Arizona, have been received from Mr. Richard W. Barringer, of Philadelphia. An interesting collection of crystalline masses of orpiment arsenic trisulphide) from the Herja mine, Chiuzbaia, Rumania, has been purchased; the collection represents the whole of the first find of this mineral at Chiuzbaia (formerly Kisbanya, Hungary).

\section{Wellcome Historical Medical Library}

THE re-opening, at the Wellcome Research Institution. 183 Euston Road, London, N.W.1, of the Wellcome Historical Medical Library was marked by a lua heon attended by a number of distinguished librarians and others interested in the history of medicine and the allied sciences. After the luncheon, an address was given by Dr. Ashworth Underwood, director of the Library and of the Wellcome Historical Medical Museum. Dr. Underwood recalled that both the Library and the Museum had been built up as a private interest by the late Sir Henry Wellcome. The Library consists of more than 200,000 volumes, many of which are extremely rare. The collection of incunabula (books printed before the end of the fifteenth century) contains 632 volumes and is the second largest collection of medical and cognate incunabula in the world. Equally important is the sixteenth-century collection, which contains a number of hitherto unrecorded works. Sir Henry Wellcome began his collection about 1895, and thereafter he had frequently added as many as two thousand volumes a year, and in one year the number reached more than five thousand. His collection of incunabula was commenced some time before 1897, and by the First World War he had more than two hundred and fifty. The Library is one of the world's greatest collections, built up by a single individual, and its importance for the study of the history of medicine and the sciences is very great. Dr. Underwood paid a tribute to the work carried out by Mr. W. J. Bishop, the librarian, Mr. F. N. L. Poynter, the deputy librarian, and the staff of the Library, in bringing it to its present condition.

Apart from many works of extreme value for the history of medicine, the Library is very rich in special collections ; for example, works of travels (especially those containing early descriptions of tropical diseases and of the indigenous materia medica); botany; alchemy (one of the finest collections in the world); occultism ; tobacco ; plague ; archæology ; anthropology and folk-lore. In addition, there is a very com prehensive collection of modern bibliographical and reference works. The Library is for reference only, and no books can be lent. There is ample accommodation for readers, and there are facilities for photographic reproduction. Prints, lantern slides and photostat copies can be supplied, and there is also a microfilm service, with a reading machine installed in the Library. Although the Library is primarily intended for the use of students of the history of medicine and the sciences, access is freely granted to any serious inquirer. Indeed, the resources of the Library are admirably suited to postgraduate study in historical topics that are not specifically medical, and valuable information may be found touching on social history and the social sciences, religion and philosophy, literature and the arts, technology and archæology, especially Egyptian. There are also comprehensive biographical and bibliographical col. lections. Historical and bibliographical inquiries can be dealt with by the Library staff; these should preferably be made by letter. A general catalogue of the Library in short-title form is now being prepared for the press. Scientific and other societies can arrange for special visits to the Library, which is open on Monday to Friday from 10 a.m. to 5 p.m.

\section{Ultra-Violet Radiation in Industry t/f}

ON Decenpare 1 a small but interesting demonstration on esitra-violet radiation in industry was given by Hdnovia, Ltd., at 3 Victoria Street, London, S.W.1. The demonstration was divided into three parp showing respectively: photochemical and phdtobiological reactions; fluorescence and phosphorescence ; and a selection of ultra-violet lamps in stock and in current use. In the first section was illustrated the use of ultra-violet radiation for the production in a few hours or days of the effect of several years of bright sunlight, by which means the deterioration of dyes, paints, varnishes, metal surfaces, etc., can be rapidly tested. Other photo. chemical reactions included the polymerization of methyl methacrylate for joining 'Perspex' sheets, the isomerization of ergosterol into calciferol (vitamin $D_{2}$ ) 